\title{
Corporeality in Context of Problem of Human Identity: Body of Protest as Form of Individual Social Representation
}

\author{
Vladislav O. Sheleketa ${ }^{1, *}$, and Sophia V. Batzanova ${ }^{2}$ \\ ${ }^{1}$ BSTY named after V. G. Shoukhov \\ ${ }^{2}$ Belgorod State Technological University named after V. G. Shoukhov, Russia
}

\begin{abstract}
The article is devoted to socially representative dimensions of human corporeality, considered in the context of social experience. At the same time, social experience is taken by the authors, first of all, as a torture of protest, where the protest is conceived as a constituting factor of self-reflection. Analyzing the phenomenon of corporeality through the prism of the communicative element, as well as a representative of the manifestations of human consciousness, the authors proceed from a theoretical premise: corporeality returns itself, its presents in postmodern neo-postmodernism as a spontaneous sensuality of mass culture that breaks through taboo. The main aspect of corporeality is corporality, acting as the result of communicative action and presenting us to the other in the act of communicative action. At the same time, the authors introduce the concept of "prosthetic solidity" and prove that a demonstrative change in the body, in our opinion, is the most radical, vivid and ambiguous form of protest corporeality. In the article, the various forms of protest corporealityare analyzed. The main categories which were analyzed in the article are: protest corporality, communicative space, protest movement, social representation.
\end{abstract}

\section{Introduction}

The problem of corporeality as the primary identity of manexcited philosophers was raised in the earliest stages of appearance of person's reflection. In the space of corporeality, located in the sphere between the dualism of the soul-body. The spiritualization of the body and the exhalation of the soul was overcome (according to V.P. Zinchenko) [10]. At the same time, the category "between" demonstrates, in our opinion, the social or rather communicative and social nature of corporality. However, it should be noted that the definition of the mode of sociocommunicative identity as a bodily representation of man is extremely inadequate.

In the history, philosophical reflection became one of the poles of the dual self-identity of Plato. The flawed, coloured in negative shades of non-existence, reached apogee within the framework of medieval theology. The corporality in the sacral aspect also had its status at the lowest stages of the sacral, and this corporeality declared itself during the Renaissance. Mostly as hypertrophied sensuality, demonstrating probably the law of psychological compensation, it is rooted in the very being. Thus, the visually sensory representational power of corporeality only begins to manifest itself.

Passing through ignoring oneself in the age of the cult of reason, in the era of enlightenment, there was growing in additional dimensions, returning itself to the philosophy of life of the nineteenth and twentieth centuries. That time, corporeality reached the postmodern era and was fixed in the philosophy of postmodernism and poststructuralism in the diffuse forms of the world of structurelessness, whose origin in art was expressed in his canvases by S. Daly. Here the protest elements of self-identification come.

\section{$2 \quad$ Materials and methods}

At the same time, at least as a repository of the soul, consciousness, corporeality, being, beingness in postmodern neo-postmodernism return as a spontaneous sensuality of mass culture that breaks through taboo. And not only culture. If mass consciousness is always defined as one of its main modes - a mode of corporeality, even more so - in the context of the activity manifestations of a political man as an actor of social action. Even Habermas and Comte defined man as an agent of action, and, despite the fact that the idea of the spiritual priority is unconditional and hopeless in the European consciousness, corporeality is not simply an antipode of the soul, a mechanically dense body. But it is modeled as an organ of activity for the soul, the organ of representation, the manifestation of the being of the soul.

The main intention "focus-on" is the task of corporality and, at the same time, the spatial localization of any forms of activity of consciousness. This process begins with a disposable world of imagination and ends mental categorization, because the objects are located in the body, in its essence, virtuality. In addition, categories, in contrast 
to objects of the imagination, have a share of bodily spatiality as a kind of "flesh" of thought. All the above events are reflected in the interior, existential terms.

The experience of philosophical reflection concerning the problem of corporality as a social representative in the 20th century has to do with M. Buber's theories of dialogality (corporality as being born between the "I-You"), M. M Bakhtin ("I am different", "I - a stranger "), as well as to the psychological modes of Vygotsky (the mediation of the transition from the intra -individual to the intra individual), and so on.

Thus, the main aspect of corporality is corporality, acting as the result of communicative action and presenting us to the Other in the act of communicative action. As P. Tishchenko writes, "... the same appearance, which we usually call a body, in fact, in the same living sensory experience, always directly presents us with the soul, desire, consciousness of will, etc. "Ideality" of another person and oneself ". We communicate directly with each other, without creating, at the same time, additional actions necessary for understanding. In this case, we are talking about the process of translating "external" (corporeal), into the language of the "inner" (mental) language. What metaphysics hides in the "inner" is directly present in the living experience. The word or smile of the other pleases or saddens the soul directly. The foregoing is to be understood from the conventional point of view, since interpersonal only conditionally to a certain extent can be divided into physical relations (for example, physiological), metaphysical ("I" and "You"), and psychological, etc. [7].

This can be described as one of the "modern practices of oneself." This is the hermeneutic position of modern man.

In the human anthropological reality, the sphere of corporeality is a constitutive element. This is indicated by its social presentation, in the first place. The main representants of human existence, that is the primary application of human of its existence, is that it belongs to the biological existence, as any manifestation of the phenomenon of spirituality we somehow fix our receptors. And this is not just an expansive understanding of corporeality, but a fact.

At the same time, corporeality is simultaneously constructed. It occurs in any act of the activity of the personality, acting on the body as a sheet of papyrus, and writing its own writings. The whole society stands out as the cryptogoraph. In this sense, the body is a universal instrument, embracing all aspects of life with its representative action.

Here the question arises: "Is it possible to talk about" the corporeality of the ethical, "the corporeality of the political, "the corporeality of the social"? In domestic philosophical studies devoted to the theme of corporality, this problem is shown from the standpoint of a position that allows such an opportunity to distinguish various "bodies" in a person, probably taking cultural and historical determinants as a criterion for this systematization. Thus, P. Tishchenko writes about the "body of suffering", the body of pain, etc. in their reflections of the phenomenon of corporeality, devoted to the existential aspects of the integrity of human being [8, pp 35-47]. Thus, P. Tishchenko shows that the doctor and medicine as a whole are fixators of these states-drawings, creativity of the spirit on the body. In this sense, the "biological body" that becomes "the body of the medical" is the "main body", because it initiates the process of transcending as an "extension to nothing" - the defining characteristic of the person's existence.

\section{$3 \quad$ Results and Discussion}

Meanwhile, including the "body of suffering" in the corporeality of social representation, our task in the framework of the analysis is to show the role of the "body of the social" or "body of protest".

Presence in reality is given through suffering - this is the axiom of existential trends in philosophy of the 19th and 20th centuries. And in this sense, S. K. Tumbes, who wrote: "At the pre-reflective level, the body is not represented explicitly for consciousness. Man is simply present in the world, captured by his life projects. In the implementation of these projects the body is a "transparent". For example, if I'm reading a book, my attention is completely focused on the meaning of the text. I do not notice the work of the eyes that provides reading. That subjects the activity of consciousness is the meaning of the text. However, if my headache and reading become difficult, my attention shifts from the meaning of the text and focuses on trying to understand the cause of the difficulty. I am aware of the source of the difficulty as pain and localize it in the eyes [9, p. 34]. "At the same time, the body is not autopsychic, to realize itself through its sensations. It comprehends its dimensions (as in the general body-spirit system) through communicativeness. In this sense, it is impossible to speak, of course, of the "tele communicative". Rather, it is about the "body of protest", while this body is not an expression of explicit socially oriented actions (although the latter manifest the body most prominently in the light of the public, highlighting the entire spectrum of human being. "The body of protest" simultaneously identifies the person, building his system interactions with the world, because on the one hand, protest as a form of disagreement with the existing state of things is an expression of the existence of the critical nature of consciousness. On the other hand, it is manifested in various social acts and actions, on visually able to show the "letters of the spirit" on himself.

In the modern world, statements about their existence, needs made orally become increasingly problematic. And the question is not only in tabooing and the growth of censorship, coming from political and economic power. The statement may simply not be heard - due to the large volume of information flows, which are often perceived by a person as "information noise". Student movement, actions dedicated to freedom of speech, freedom of choice, protests aimed at depriving a person of real constitutional rights today are phenomena of total or mass corporality. Obviously, that is a fundamental characteristic of the sociocultural reality of the postmodern era, a culture in the space of which the effectiveness of the word as such is gradually lost, as the radical oppositions of the classical type of civilization are no longer effective and the person is captured by a flow of visually-bodily sensations. And the protest basically becomes corporeal.

The history of the protest pervades the whole history of mankind. From riots and uprisings to demonstratively high collars and glasses, the range of protest phenomena has 
always been wide and varied. Protest behavior is far from always just a bright, raging human sea, in one rush overcoming the hated features of the social system. The forms of protest are much more diverse and complex.

In modern Western society, the protest becomes refined subtle. Objects of protest are phenomena that are hushed up or denied by the majority. The death of animals, abortion, environmental problems can not be the reason why a lot of people will come out with a protest on the street. All the mass protests observed in recent years are protests against the violation of social and constitutional rights, corruption. These are protests, where according to J. Butler "... about the bodies that act together. Not the only body establishes the manifestation space, but the action; this performative experience happens only "between" bodies, in a space that establishes a gap between my own body and that of another. Thus, my body does not act alone when it acts politically [1]. "But protests against a different range of problems also exist in European culture and are also directly related to corporality.

In these protests, the main role is played by the individual body, becoming a canvas for protest demonstration. On the news agencies that are in the news tapes, we are faced with a series of protests in which the human body is called upon to fulfill the same role as slogans in demonstrations. In this case, the use of the body as a poster or canvas - the practice is equally uncomfortable, both for the one who protests, and for those who see and understand this protest. At the simplest search query "body of protest" the system gives us from 5000 images of naked bodies, meaningfully and creatively interpreting the idea of protest.

The human body is both understandable and vulnerable, its external presentation does not have a secret, but there is a unique sense of denial of exposure and a clear attachment of this process to certain places. Leaving aside the private space, which in the modern information flow becomes conditional and a phenomenon with blurred boundaries, a person strives to build a new the space of your body. To characterize this new formation, the term introduced by M. Foucault, the "heterotopy," can be used with sufficient reason. The philosopher considered such "real spaces characterized by special interrelations between space and time, producing special regimes of corporeality and subjectivity"[2], as first of all prisons, hospitals, brothels, resorts, colonies, ships, places where there are opportunities for transformation of subjectivity. The street is not included in the Fukian or modern, existing with the amendments list of heterotopia. A naked body on the street is a challenge even in a society whose members have significantly become bare over the last hundred years. Protest by a vulnerable, open human body is not only attracting attention to the problem, it is also a challenge to a society that accepts the problem, but at the same time embarrassing manifestations of such a corporeality.

For further discussion about the types of such protest, it is necessary to define the concept of protest solidity, in our view, protest corporality can be characterized as a set of social and cultural codes informing in disagreement with social standards and perceptions. Corporeality appears as an integral characteristic of the existential experience of man; a complex of natural, cultural and individual qualities of the human body; the field of interaction of the inner and outer living spaces of man; mastered in the course of socialization by various body languages.

A distinctive feature of the protest body is that it transforms the private, personal space of corporeality into a public, political, creating the phenomenon of a man-protest. This trait can be characterized by the phrase by Khanish K. "personal this is political" [5], our interpretation, at first glance, goes away from radical feminism, but protest solidity in itself is radical.

Protest corporeality today (in our opinion in different historical epochs, protest corporeality had various manifestations) can be represented in several forms: collective artistic protest; collective protest, group protest, individual protest with images on the body, body-poster; demonstrative change of body.

Collective artistic protest of naked bodies is an intellectual and artistic challenge, in which dozens of people are involved. It has a single artistic solution, its own internal structure, logic and development. A vivid example of such a protest is a protest against bullfighting, running of bulls in Pamplona, for animal rights. All participants of this protest have common emblems, body coloring, most often depicting blood flows, working together, combining a flash mob with an art installation dedicated to the problem, and emphasizing disagreement with the position of the authorities.

Collective individual protest with images on the body, body - poster; demonstrative change of body takes its roots in the gymnastic culture of the beginning of the century, when words and pyramids from the bodies were part of the physical parades. The meaning of the collective protest is not only in demonstrating a naked, wounded human body, followed by the very problem itself, but in drawing up a transpersonal sense in the form of a figure or a word demonstrating to the world the position of the protesters. An example of such a protest can serve some of the work of photographer Spencer Tunic, who uses photographs with hundreds of nudes to draw attention to various problems of society: equality, environmental pollution, lack of sleep, installation against the war [4].

Group protest of naked bodies is the most widespread and brightest form of protest corporality. Activists of the GreenPeace and other organizations that protect animal rights, vegetarians and environmentalists use for their protest not just a naked and wounded body, they are trying to ensure that this body was as close as possible to the person - the king of nature, with the main figure of civilization. The body becomes not just a canvas, it is a piece of meat that is creatively tightened with plastic wrap, put in plastic containers, like portions of meat in the refrigerator, put on it a drawing depicting an animal, smeared with oil, like birds caught in oil slicks. The body in this case is flesh, devoid of a person whose flesh is denied in thinking, flesh, for the sake of the flesh, the realization in practice of the greatest human fear - the fear of ceasing to be a man.

An individual protest with images on the body is the brightest possible manifestation of a protest body, a vulnerable and naked body exhibited parade, deprived of even conditional protection in the form of the same bodies alongside demonstrates its position by letting random people into its private zone. Bringing the private into the public, 
refusing to recognize the place of action unfit for such a form of manifestation of social and political activity causes a greater wave of anger and resentment than collective forms [3].

\section{Conclusion}

Demonstrative change of the body, in our opinion, is the most radical, vivid and ambiguous form of protest corporality, its example is the branding of self-defenders with iron, calling for humane treatment of animals. Carrying someone else's experience on themselves, drawing attention to the problem of someone who cannot express their attitude himself. Sharpening the focus on the identity of human and animal flesh, depriving a person of the status of the top of evolution is not just a matter of solving the problem, but also posing a whole host of new ones related to the status of man in the world.

Summarizing all of the above, we can talk about the corporeality that interests human being in its integrity as a corporeality of communicative-protest. The undeveloped nature of this problem is compensated by the enormous importance of this dimension, which is actualized in the modern world. In this sense, a person finds his being in a situation of protest - against the resistance of the world, being as a whole, in the process of which he identifies his being as "I-being" and "here-being". The very act of reflection is already protesting, because it looks at existence from any distance. In this sense, the act of primary selfrepresentation as a Cartesian cogito is pre-reflective or "protestative" in its essence. Displaced dynamically from the socio-political reality of the protest movement is, especially, the most active form of social reflection, the living flesh of social action, and the body of protest today reveals its kinship with the social body, with the reality of social acts that declare their social and political preferences the individual.

The article was implemented in accordance with the program of the "Strategic development of the BSTU named after VG Shukhov for 2017-2021"

\section{References}

1 J. Butler, Union of bodies and street politics. [Electronic resource]. Access mode: https: //studaction.wordpress.com/analytics/bodies_in_allianc e/ (Date of circulation 04/30/2018)

2 O.V. Bezubova, Aesthetics of architecture and design: Materials Vseros. scientific-practical. Conf. (M.: Architecture-S, 2010)

3 M. Foucault, Will to truth: beyond knowledge, power and sexuality (Moscow: Magisterium. Ed. house "Kastal", 1996)

4 Gololyud Spencer Tunic again will undress all [Electronic, resource]. Access mode: http: // http: //bigpicture.ru/? $\mathrm{P}=771850$. (Date of circulation April 22, 2018)

5 K. Khanish, Personal - this is political [Electronic resource].
Access http://womenation.org/hanisch-personal-is-politica. (Date of circulation 30.04.2018)

6 Naked woman on a plate with vegetables protested against the murder of turkeys [Electronic resource]. Access mode: http://120.su/ (Date of circulation 24.04.2018)

7 P.D. Tishchenko, Bulletin of Siberian medicine 5, 35-40 (2006)

8 P.D. Tishchenko, Bulletin of the Siberian medicine (2006)

9 S.K. Toombs, The meaning of illness. A Phenomenologic (Account of the Different Perspectives of Physician and Patient. Dordrecht, 1993)

10 V.P. Zinchenko, T.S. Levi, Psychology on the swing between the soul and the body (M., 2005) 